\title{
A primitive rabbinic calendar text from the Cairo Genizah
}

\author{
S A C H A S T E R N
}

U N I VERSITY COLLEGE LONDON, UK

\begin{abstract}
Aвstract A hitherto unnoticed fragment from the Cairo Genizah, T-S K2.27, describes two methods for calculating the calendar that ignore the molad and differ in further ways from the later, fixed rabbinic calendar. These 'primitive' rabbinic calendars, which I would date to the eighth century at the latest, are based on calendar rules attested in the Palestinian Talmud but also attempt, not very accurately, to turn the Jewish calendar into a fixed cycle. These calendars represent an early attempt to fix the Jewish calendar. They may be seen as a missing link between the empirical, new moon-based calendar of Mishnaic and Talmudic sources and the molad calendar that became standard in the later medieval period. They also suggest that the fixed rabbinic calendar was originally formed in the early Middle Ages by emulation of the Christian Easter cycles.
\end{abstract}

$\mathrm{T}$ HE JEWISH CALENDAR as it is known today, based on a fixed calculation and set of rules, is first attested in the ninth century, and probably reached its final form in the first half of the same century. ${ }^{1}$ Not much is known about the Jewish calendar in the preceding centuries. It has long been assumed that other, less accurate calendar calculations were designed before the present one was finalized; and elements of such calculations can be found, for example, in the late-eighth-century Baraita deShemuel. ${ }^{2}$ But attempts to

I. By 'calendar' I do not mean, in this article, a comprehensive list of days and months of the year (as depicted, for example, in wall calendars), but rather the bare structure of the calendar, i.e. how days and months are structured and counted. This article was researched and written as part of the ERC Advanced Grant project 'Calendars in Late Antiquity and the Middle Ages: Standardization and Fixation', at UCL. I am grateful to Nadia Vidro for her comments on an earlier version; her contribution to the discovery of the fragment is acknowledged below in the main text. Assistance on specific points was also given by Willem Smelik, Judith Schlanger, Edna Engel and Marina Rustow.

2. See S. Stern, 'Fictitious Calendars: Early Rabbinic Notions of Time, Astronomy, and Reality', Jewish Quarterly Review 87 (1996), pp. I03-29, on pp. II7-29 (but the data in this article is inaccurate and in need of correction).

JOURNAL OF JEWISH STUDIES | vOl. LXVII NO. I | SPRING 20I6 | pp. 68-90 | ISSN 0022-2097| https://doi.org/I0.18647/3259/JJs-2016 | https://orcid.org/oooo-0002-I2I6-5860 | COPYRIGHT $(\subset)$ Oxford Centre for Hebrew and Jewish Studies, 2016.

¿ Open access article under CC-BY-NC-ND licence, freely available from the $J J S$ website. 
reconstruct such earlier calendars have never been more than conjectural. ${ }^{3}$

A hitherto unnoticed fragment from the Cairo Genizah, T-S K 2.27, presents for the first time explicit evidence of fixed calendars from this earlier period. The calendars that are described in this text, which I would identify as Palestinian and of the eighth century at the latest, differ substantially from the Jewish calendar as it is known today. These calendars are clearly rabbinic, in that they classify years as defective, orderly or full, ${ }^{4}$ and that they prohibit the New Year from falling on Wednesdays or Fridays; these rules are specifically rabbinic (the latter is already attested in the Palestinian Talmud), and cannot be associated with any other Jewish tradition (e.g. Qaraite). But some of the distinctive features of the later rabbinic calendar are conspicuously absent: the prohibition of the New Year on Sundays, and the calculation of the molad (astronomical new moon). The absence of these features locates the calendars of T-S K 2.27 at an early stage in the history of the fixed rabbinic calendar, when attempts were being made to standardize and fix the calendar, but not all its principles and rules had yet been formulated or conceived. For this reason, it is perhaps appropriate to refer to these calendars as 'primitive'. They represent a missing link between the empirical, new moon-based calendar of Mishnaic and Talmudic sources and the fixed calendar that became standard in the later medieval period. ${ }^{5}$

In this article, where this fragment will be edited for the first time, I shall argue that these early calendars (or at least the 'verso' calendar in T-S K 2.27) attempt not only to fix the Jewish calendar but also to turn it into a cycle that repeats itself within relatively short periods of years, in contrast to the later rabbinic calendar which is not cyclical or reiterative. The cyclicity of these calendars comes at the cost of astronomical accuracy, a virtue in which,

3. Most notably by Z.H. Jaffe, Qorot Heshbon ha-’Ibbur, ed. A.A. Akavia (Jerusalem: Darom, I93I); also H.Y. Bornstein, Divrei yemei ha-'ibbur ha-aharonim, pt I, ha-Tequfah I4-I5 (I922), pp. 32I-72, and pt 2, ibid. I6 (1922), pp. 228-92. For a critique of this approach, see Akavia, Qorot Heshbon ha-'Ibbur, pp. II-I6, and idem, 'Baraita de-Shemu'el ke-Te'udah le-Toledot ha-'Ibbur', Melila 5 (I955), pp. I19-32.

4. Defective: the months of Marheshwan and Kislew are both defective, i.e. of 29 days. Orderly: Marheshwan is defective and Kislew is full, i.e. of 30 days. Full: both months are full. The characteristic of 'defective, orderly and full' can be used interchangeably with reference to the year as a whole or more specifically to the months of Marheshwan and Kislew. Besides the characteristic of 'defective, orderly and full', the year can be 'plain' (I2 months) or 'intercalated' (I3 months).

5. On the history of the rabbinic calendar, and its evolution from a calendar based on monthly, empirical sightings of the new moon crescent (in Mishnaic and Talmudic sources of late antiquity) to a fixed scheme based on an astronomical calculation (by the ninth century), see S. Stern, Calendar and Community: A History of the Jewish Calendar, 2nd cent. BCE-1oth cent. CE (Oxford: Oxford University Press, 200I), chs 4-5. 
in contrast, the later rabbinic calendar notoriously excels. The similarity of these calendars to contemporary Christian Easter cycles, which I shall also point out, reinforces the contention that in many ways the fixed rabbinic calendar was formed in late antiquity and the early Middle Ages through emulation of the Christian calendar.

\section{The manuscript, text edition and translation}

The text that is extant, in Aramaic, survives on the half of one bi-folio, T-S K 2.27 (recto left and verso right - see FIG. I and 2 at the end of the article). The beginning of the text is extant as it begins, rather fortunately, on the first line of the recto; only the end of the text (after the end of verso right) is missing. The other half of the bi-folio contains a description in Hebrew of the later rabbinic calendar (as it is known today); it will not be edited in this article, as the information it presents is largely well known and outside my present scope. Another Cairo Genizah bi-folio, T-S NS 98.32, entirely in Hebrew, belongs to the same manuscript and contains further information on the later rabbinic calendar. Both fragments were discovered and joined by my colleague Nadia Vidro, who immediately recognized the significance of the Aramaic text. The credit for the discovery is hers, and I am grateful to her for passing it on to me for publication.

The contents of these bi-folios suggest that they formed part of a small codex devoted partly or wholly to calendrical matters. The join between the two bi-folios is continuous: as we shall presently see, T-S K 2.27 (recto left) continues T-S NS 98.32 (recto right), whilst T-S NS 98.32 (recto left) continues T-S K 2.27 (recto right). ${ }^{6}$ Judging from the contents of the texts, T-S NS 98.32 belongs most likely inside T-S K 2.27, with the innermost bi-folio(s) missing, and either the outermost bifolio(s) or other quires, at the beginning and end, similarly missing. This arrangement makes it possible for the text to have begun with the fundamental elements of the calendar, before elaborating on various themes in more detail. Accordingly, our Aramaic text of 'primitive' rabbinic calendars would have appeared towards the end of this small treatise:

6. (T-S K 2.27 recto right, last line) שנה שנייה ל'ירי'ל' שנה שלישית ריו'ל'ל' שנה (NS 98.32 recto left,

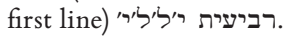


T-S K 2.27 (verso left): fundamental elements of the (later) rabbinic calendar T-S K 2.27 (recto right): calculation of the tequfah (equinoxes and solstices) NS 98.32 (recto left): the same, continued

NS 98.32 (verso right): the same, end. Night visibility of the moon. ${ }^{7}$

Inner bifolio(s): (at least 4 sides, missing).

NS 98.32 (verso left): correspondences between festival and other dates in the year.

NS 98.32 (recto right): the same, continued.

T-S K 2.27 (recto left): the same, end (on line I). Primitive rabbinic calendar I (Aramaic).

T-S K 2.27 (verso right): Primitive rabbinic calendar 2 (Aramaic).

The manuscript is relatively late, and can be dated, on palaeographical grounds, to the thirteenth century. ${ }^{8}$ Inasmuch as our text presents a primitive rabbinic calendar that was superseded and abandoned by the ninth century, its preservation in a late medieval manuscript is all the more remarkable.

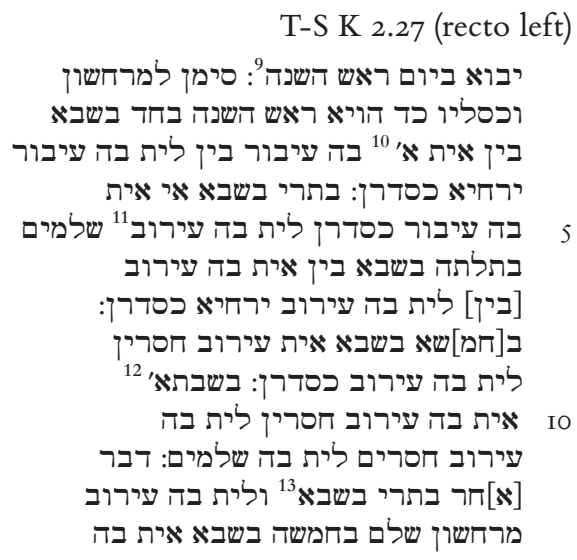

7. Although this is outside the scope of this article, I should mention in this passage of T-S NS 98.32 the unusual word פנתורי, which designates a division of the hour into five parts: every night of the waxing moon, the moon becomes visible for four parts (4/5 hour) longer. The word פנתורי is clearly derived from a Greek word $\pi \varepsilon \mu \varphi \theta \omega \rho \alpha$ ('fifth of the hour'), but this word is unattested in Greek sources (I am grateful to Alexander Jones and François de Blois for their advice).

8. Judith Schlanger and Edna Engel, personal communications (I8-I9 May 2015).

9. These first four words, in Hebrew, follow and end the Hebrew text on NS 98.32, which reads (recto right, last two lines): חנוכה ביום ערבה / אם אין מרחשון מלא ואם הוא מלא.

Io. The prime marks this letter for deletion.

II. Erroneous metathesis for עיבור; the error continues through the rest of the document.

I2. This prime is a space filler.

I3. Stroke above the $\boldsymbol{w}$; this may be related to the $ב$ overriding something else erroneously written. 


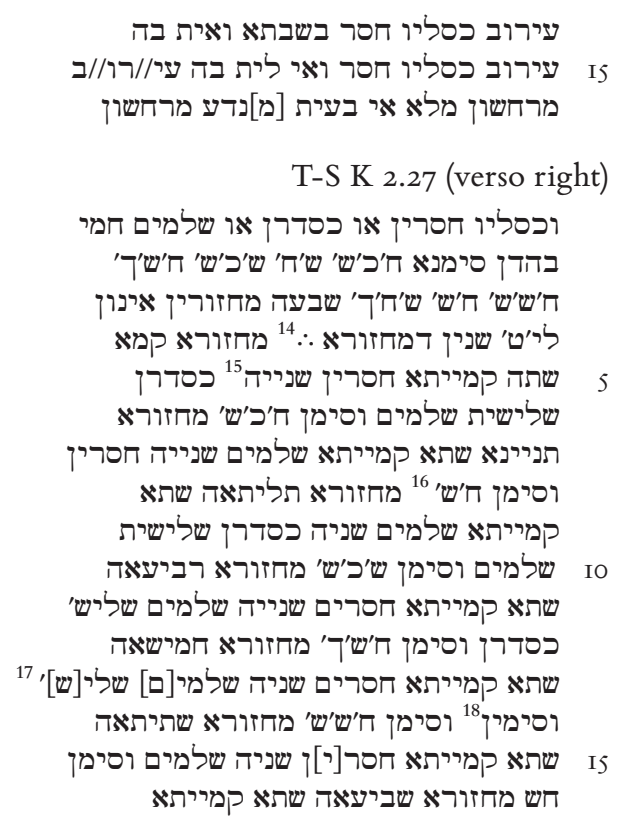

T-S K 2.27 (recto left)

it will occur on the (same) day of (the week as) the New Year. ${ }^{19}$ The sign for Marheshwan

and Kislew ${ }^{20}$ is (as follows): when the New Year falls on Sunday, whether there is in it an intercalation or no intercalation, ${ }^{21}$ the months are orderly. On a Monday, if there is

5 in it an intercalation, they are orderly; no intercalation, they are full. On a Tuesday, whether there is in it an intercalation

I4. Three dots in a triangle.

I5. Although the use of Aramaic in this text is fairly consistent (with the exception of some technical Hebrew phrases such as דבר אחר ,ראש השנה, and the arguably Hebrew terms חסר מלא (מ), this ordinal number is in Hebrew, and so in the continuation of the passage. The reason for this language switch is probably to distinguish between the numbering of years, for which Hebrew ordinals are used (except, rather oddly, for the first year, which is always numbered in Aramaic, קמייתא), and the cycles, for which Aramaic ordinals are used (e.g. מחזורא תניינא).

I6. An error for ' 1 '

I7. The expected שלמים is missing after this word; but below I argue that the missing word is in fact כסדרן, and that the sign should be corrected to '

18. The word is marked as erroneous with a stroke above it.

19. This marks the end of the previous passage, in Hebrew, on correspondences between festival and other dates in the year. The last two lines of NS 98.32 (recto right - see above, n. 9) translate as: 'Hannukah [25 Kislew] is on the (same day of the week as the) day of the willow [2I Tishri] if Marheshwan is not full; but if it is full, ...' The Aramaic, primitive calendar text begins at this point. 2o. I.e. the way of knowing whether the variable months in the year, Marheshwan and Kislew, are defective (29 days) or full ( 30 days) in any given year. See above, n. 4 .

2I. I.e. the intercalation of a second month of Adar in the coming year. 
or no intercalation, the months are orderly.

On a Thursday, (if) there is an intercalation, they are defective;

no intercalation in it, they are orderly. On Sabbath,

Io (if) there is an intercalation in it, they are defective; no

intercalation, they are defective, ${ }^{22}$ no (intercalation) in it, they are full.

Another

version: on a Monday and there is no intercalation in it,

Marheshwan is full. On a Thursday and there is in it

an intercalation, Kislew is defective. On a Sabbath and there is in it

I5 an intercalation, Kislew is defective; and if there is no intercalation in it, Marheshwan is full. If ${ }^{23}$ you want to know whether Marheshwan

T-S K 2.27 (verso right)

and Kislew are defective (D), orderly (O), or full (F), look

at the following sign: DOF FD FOF DFO

DFF DF FDO - these are seven (small) cycles

of the I9 years of the cycle. ${ }^{24}$ First (small) cycle:

5 first year defective, second orderly, third full; and the sign is DOF. Second

cycle: first year full, second defective;

and the sign is FD. Third cycle: first

year full, second orderly, third

Io full; and the sign is FOF. Fourth cycle:

first year defective, second full, third

orderly; and the sign is DFO. Fifth cycle:

first year defective, second full, third; ${ }^{25}$

and the sign is DFF. Sixth cycle:

Is first year defective, second full; and the sign is

DF. Seventh cycle: first year ${ }^{26}$

\section{Date and provenance: the 'primitive' features of T-S K 2.27}

Before I consider the text in full, one phrase, on the second line of the recto, requires immediate comment: 'when the New Year falls on Sunday'. As is well known, the later rabbinic calendar (now standard Jewish calendar) prohibits

22. This is clearly an error, as is further confirmed below. As the scribe goes on to correct (which results in an apparent repetition), it should be 'full'.

23. Here begins what I call the 'verso calendar'.

24. The sign consists of Ig letters (D, O or F) for the ig years of the cycle of intercalations. These letters are grouped into seven small 'cycles' of two or three years each, each small cycle consisting of one or two plain years followed by an intercalated year. 'Cycle' in this context is a misnomer, since the sequences of two or three years are not cyclical in any way.

25. The year type of this third year is erroneously omitted; below I argue that it should be 'orderly', and the sign should be corrected to DFO.

26. The text breaks off here, but the continuation would have been: 'first year full, second defective, third orderly; and the sign is FDO'. 
the New Year from falling on Sunday, Wednesday or Friday, a rule popularly known already in early-ninth-century sources as lo $A D U$ Rosh. The rule is explicitly stated in the exilarch's calendar letter of $835 / 6 \mathrm{CE}$, and implicit already in al-Khwarizmi's treatise on the Jewish calendar of $823 / 4 \mathrm{CE} .{ }^{27}$

In earlier sources, however, the New Year on Sunday was not prohibited: thus a Sunday New Year date is implicit in the date of death of Rav Ahai b. Rav Huna as recorded in the Epistle of Sherira Gaon (Sunday 4 Adar 8I7 SE, i.e. 506 C E), and also assumed as a possibility in the Palestinian Sefer ha-Ma'asim (seventh century). Although the prohibition of the New Year on Sunday draws its roots from the Palestinian Talmud (pSukkah 4:I, 54b), it was contentious in the Talmudic period and not accepted as an established rule. Indeed, another passage in the Palestinian Talmud ( $\gamma$ Megillah $\mathrm{r}: 2,70 \mathrm{~b}$ ) clearly indicates that only Wednesday and Friday were forbidden days for the New Year - exactly as in our present text. ${ }^{28}$

The assumption, in our text, that the New Year can occur on Sunday is therefore not problematic, but clearly dates it to no later than the eighth century. By the ninth century, indeed, the rule against this became so standard in the rabbinic calendar that it could not have been contravened without at least a word of justification.

There are further indications that this text dates to no later than the eighth century. The verso of T-S K 2.27 presents a I9-year cycle that has the following configuration:

$$
3-2-3-3-3-2-3 \text { (total: } 19 \text { years) }
$$

The 19-year cycle is thus divided into seven small 'cycles', each ending (in the third or second year) with an intercalated year (this is not explicit in the text, but the only possible interpretation). This model differs from that

27. Exilarch's letter: Stern, Calendar and Community, pp. 277-83. Al-Khwarizmi: E.S. Kennedy, 'Al-Khwārizmī on the Jewish calendar', Scripta mathematica 27 (1964), pp. 55-9; T. Langermann, 'When Was the Hebrew Calendar Instituted?', Assufot I (1987), pp. I59-68 (in Hebrew); F. de Blois, 'Some Early Islamic and Christian Sources Regarding the Jewish Calendar (9th-I Ith Centuries)', in S. Stern and C. Burnett (eds), Time, Astronomy, and Calendars in the Jewish Tradition (Leiden: Brill, 20I3), pp. $65-78$. The rule is also mentioned in the Halakhot Pesuqot, a work attributed to Yehudai Gaon of the mid-eighth century, and in one recension of a piyyut of his contemporary or slightly later R. Pinhas, but these passages could easily be later interpolations. See further Stern, Calendar and Community, pp. I82-4, I94-5.

28. Stern, Calendar and Community, pp. I66-7, I7I-2, I82-3, I94-5. The interpretation of the Sefer ha-Ma'asim passage has been contentious, but I side with the arguments of M.D. Herr, 'Matters of Palestinian Halakha during the Sixth and Seventh Centuries C.E.', Tarbiz 49 (1979/80), pp. 62-80 (in Hebrew). 
assumed in the present-day rabbinic (or 'Jewish') calendar, $3-3-2-3-3-3-2$, which became standard around the eleventh century. The model of our text appears not uncommonly in ninth-tenth-century sources, but already in this period it was identified by at least one author as 'ancient' and outdated. In a calendar treatise that has been plausibly dated to the early tenth century, its author Joshua ben Allan associates this model of the I9-year cycle with 'the first sages' (החכמים הראשונים), in contrast to other configurations used by what he calls the 'middle sages' and then the 'sages of this generation'. ${ }^{29}$ This suggests that in his period the model of the 'first sages' was no longer in use. Indeed, as I intend arguing elsewhere, this 'first sages' model is the one assumed in the Pirqei deRabbi Eliezer, a work normally dated to the eighth century where the I9-year cycle is in fact first attested; and, as I shall argue elsewhere, the eighth century is when this cycle is most likely to have been devised. The choice, in our present text, of this model of the I9-year cycle points therefore to the eighth century.

A further aspect, and one of the most archaic or 'primitive', of the rabbinic calendars in T-S K 2.27 is the absence of any reference to the molad (astronomical new moon) and its calculation. As we shall see, this is not simply because we are missing the end of the text, and the molad happens not to be mentioned in this folio. In fact, the fixed calendar schemes that are proposed in this document are self-sufficient and do not depend on any calculation of the molad at all.

An early reference to the molad calculation appears in the Babylonian Talmud (bRosh ha-Shanah 25a), but this passage is most likely a late interpolation. A different molad calculation then appears in Pirqei deRabbi Eliezer (ch. 7) and the late-eighth-century Baraita de-Shemuel (ch. 5), but its value in these sources is much more approximate than that of the later rabbinic calendar, and it is not even clear that the molad calculation is intended there for setting calendar dates. Elements of the later molad calculation appear in a few other sources of roughly the same period, but it is only in al-Khwarizmi's treatise of $823 / 4 \mathrm{CE}$ that the molad and its calculation are first attested and given as the basis for

29. The treatise of Joshua ben Allan was published by A. Harkavy in Hadashim gam Yeshanim (Studien und Mittheilungen), Ha-Goren 8 (I903), pp. 75-80, on the basis of a manuscript that I was able to locate in the Vernadsky Library, Kiev, under the shelf mark OPI no. 286, where the relevant passage is on fol. I8b. I am grateful to Alexey Khamray and other members of the Judaic section of the library for arranging access to the library and helping me find the manuscript, in a collection which to date is still largely uncatalogued. The dating and other aspects of this work will be discussed elsewhere. 
fixing the dates of the Jewish calendar. ${ }^{30}$ As has been argued elsewhere, this molad calculation was most likely derived from Ptolemy's astronomical work, the Almagest, which had only recently been translated into Arabic in the early ninth century. ${ }^{31}$ Its use for setting calendar dates was clearly innovative, both in Jewish terms and in comparison to all other known calendars in antiquity and the early Islamic period. But it rapidly became established in the ninth century, as the molad is mentioned, for example, in the exilarch's letter of $835 / 6 \mathrm{CE}$. Any calendar text such as ours that ignores the molad and makes no use of it is likely, therefore, to pre-date the ninth century and points again to the eighth century at the latest.

In terms of provenance, the Aramaic in use in this text points towards Palestine, with in particular the distinctly Palestinian חמי (verso line I, 'look' - as opposed to the Babylonian חזי). ${ }^{32}$ The Palestinian origins of this text may be related to the possibly Palestinian character of the manuscript as a whole, whose script shows features of being perhaps Byzantine or Palestinian. ${ }^{33}$ A Palestinian provenance is hardly surprising, as in the eighth century Palestine was probably still regarded as the main or sole centre of authority in calendrical matters - as was still recognized, for example, by the Babylonian exilarch in his letter of $835 / 6$.

30. See above, nn. 2 and 27; and Stern, Calendar and Community, pp. 200-206. Even in alKhwarizmi's treatise, where the times of the molad determine all calendar dates, the molad calculation itself is incomplete as it is given without an epoch; but see the comments of de Blois, 'Some Early Islamic and Christian Sources', and Stern and Burnett, 'Preface', in Time, Astronomy, and Calendars.

3I. Stern, Calendar and Community, pp. 207-IO. The first Arabic translation of the Almagest, now lost, dates to the late eighth or early ninth century, and a Syriac translation was also in circulation in this period: see P. Kunitzsch, Der Almagest: Die Syntaxis Mathematica des Claudius Ptolemaus in arabischlateinischer Überlieferung (Wiesbaden: Harrassowitz, I974), pp. I5-82; G. Saliba, A History of Arabic Astronomy (New York: New York University Press, 1994), pp. I43-4. On the value of the lunation in Arabic versions of the Almagest, see J.L. Mancha, 'A Note on Copernicus' "Correction" of Ptolemy's Mean Synodic Month', Suhayl 3 (2002/3), pp. 22I-9.

32. In a personal communication, Willem Smelik advises that if the text dates from the eighth century or earlier, חמי can only be Palestinian; in later centuries, however, the dialects tend to mix. The demonstrative הדין (which is spelled here הדן, in the next line) is also more likely Palestinian than Babylonian (unless intended to sound archaic or conservative, which does not seem to be the register of this calendar manual). The ordinals קמייתא ,קמא (in the following lines) would normally be regarded as Babylonian in earlier sources, but by the eighth century they could also be Palestinian. 33. Judith Schlanger, personal communication; but this is very tentative. Mention might also be made of an unusual Greek word elsewhere in the manuscript (above, n. 7), which points in the direction of Byzantium and possibly Palestine. 


\section{The calendars of T-S K 2.27: the verso calendar}

The text of T-S K 2.27 presents, in fact, two very different calendar schemes; as they are conveniently laid out on the recto and verso, I shall refer to them as 'recto' and 'verso' calendars. ${ }^{34}$ This is not to say that the two calendars have nothing in common. Both calendars assume that the only unknown in the Jewish calendar is whether the year will be defective, orderly or full, and that knowledge of this variable in any given year is all that is needed for the calendar to be established. This implies that the sequence and length of the months of the year are fixed and unchanging, regularly alternating 29- and 30-day months, with the exception of two months, which are explicitly identified as Marheshwan and Kislew, which are variable and can be either both defective (29 days) or both full (30 days) or orderly (29 and 30 days in this order), and with the additional Adar (in an intercalated year) being always of 30 days. This fundamental structure is partially implicit already in the Palestinian Talmud, where at least the sequence of seven months between Purim and the New Year is considered to be fixed ( $\gamma$ Megillah I:2, 7ob), and where the intercalary Adar is of 30 days (ibid. I:7, 71a). This structure also characterizes, of course, the later rabbinic calendar. ${ }^{35}$ This is what gives the calendars of T-S K 2.27 their distinctively rabbinic, albeit 'primitive', identity.

But that the two calendars of T-S K 2.27 are different and even incompatible to one another is evident, nevertheless, almost at first glance: for in the recto most of the years are orderly, whereas in the verso (in the sign DOF FD FOF DFO DFF DF FDO) orderly years (O) are in a clear minority. It is essential, therefore, that we consider both calendars separately. For reasons of convenience I shall begin by explaining the calendar of the verso.

The verso (more precisely, the last line of the recto) of the folio begins by saying that in order to determine whether the year is defective (D), orderly (O) or full $(\mathrm{F})$ - on which basis all the dates of the year can be established - it is sufficient to refer to a single, fixed sequence of I9 years, which is

34. Interestingly, however, the manuscript does not indicate any division between the two calendars. In the rest of the manuscript (T-S K 2.27 and T-S NS 98.32) major divisions in the text are marked with three dots in a triangle, and minor divisions with a colon. In the Aramaic text the three-dot divider appears further down in the verso, but strangely not at the dividing point between the two calendars (I owe this observation to Nadia Vidro). This suggests that the scribe did not understand his text sufficiently well to distinguish between the two calendars and to place dividers in the appropriate locations.

35. Stern, Calendar and Community, pp. I7I-2, I94. 
given as DOF FD FOF DFO DFF DF FDO. This sequence, we are told, corresponds to the I9-year cycle of intercalations, which is subdivided into seven small cycles. The text goes on to explicate the sign in a tedious and perhaps unnecessary way: thus in the first small cycle (DOF) the first year is defective, the second year orderly, the third year full, and so on. This takes us to the end of the fragment.

The implication of this passage is that defective, orderly and full years always appear in this sequence within the I9-year cycle; and consequently that this sequence is repeated identically every 19 years. This would be impossible in the context of the later rabbinic calendar, where the sequence of defective, orderly and full years is never the same from one I9-year cycle to the next. The only cyclical element in the later rabbinic calendar regards the intercalation (i.e. the insertion of a second month of Adar), which follows a repetitive cycle of 19 years; but the other characteristics of the year (whether the months of Marheshwan and Kislew are defective, orderly and full) are not cyclical or repetitive, and the calendar as a whole is therefore not cyclical. In contrast, the verso calendar of T-S K 2.27 is, by implication, completely cyclical.

Besides the problem of its cyclicity, the sequence of years in the verso calendar is inherently impossible in terms of the later rabbinic calendar. This is because the application of this sequence would inevitably lead to the New Year occurring on forbidden days (Sunday, Wednesday and Friday, according to the later rabbinic rule of lo ADU Rosh). This is the case regardless of which day of the week the first New Year, in the sequence, is deemed to occur on.

TABLE I The verso calendar with the rule of lo ADU Rosh: the options

\begin{tabular}{lllllllllllllllllllll}
\hline $\begin{array}{l}\text { Year in } \\
\text { cycle }\end{array}$ & I & 2 & $\mathbf{3}$ & 4 & $\mathbf{5}$ & 6 & 7 & $\mathbf{8}$ & 9 & IO & II & I2 & I3 & I4 & I5 & I6 & I7 & I8 & I9 \\
& D & O & F & F & D & F & O & F & D & F & O & D & F & F & D & F & F & D & O \\
\hline & 2 & 5 & 2 & 2 & 7 & 5 & 3 & 7 & 7 & 3 & I & & & & & & & & \\
3 & 6 & & & & & & & & & & & & & & & & & \\
& 5 & I & & & & & & & & & & & & & & & & & \\
& 7 & 3 & 7 & 7 & 5 & 3 & I & & & & & & & & & & & & & \\
\hline
\end{tabular}

Notes: In the top row, numbers in bold indicate intercalated years (following the scheme of the verso calendar). The second row indicates the characteristic of the year, according to the verso calendar's sequence. The last four rows indicate the day of the week of the New Year $(2=$ Monday etc.); there are four options. Thus, in the first option, the New Year in year I falls on Monday (2); since this year is D (defective) and plain, the New Year in year 2 will necessarily fall on Thursday ( 5 ), and so on; the sequence fails in year II, when the New Year necessarily falls on Sunday (I). 
As can be seen from TABLE I, if the first New Year in the cycle is on Monday, it will occur on a Sunday in the IIth year, which is forbidden. If the first New Year is on Saturday, it will occur on a Sunday in the 7th year. If the first New Year is on Tuesday or Thursday, the sequence fails already in the 2nd year, with the New Year on Friday or Sunday (respectively).

In the context of T-S K 2.27, however, it is reasonable to assume that in the verso calendar the New Year is allowed to fall on Sundays, just as it is in the recto calendar (see discussion above). This opens up more possibilities, and brings us closer to understanding how the sequence of the verso calendar might have worked. As can be seen in TABLE 2, if the first New Year is on Sunday, the sequence fails already in the 2nd year, with the New Year on Wednesday. If the first New Year is on Thursday, the sequence fails in the 7th year; and if the first New Year is on Saturday, the sequence fails in the IIth year. But a longer viable sequence is when the first New Year is on Monday; it only fails in the I6th year, when the New Year is a Wednesday. Still, this is also a failure.

тавце 2 The verso calendar with the New Year on Sundays: the options

\begin{tabular}{llllllllllllllllllll}
\hline $\begin{array}{l}\text { Year in } \\
\text { cycle }\end{array}$ & I & $\mathbf{2}$ & $\mathbf{3}$ & 4 & $\mathbf{5}$ & 6 & 7 & $\mathbf{8}$ & 9 & IO & II & I2 & I3 & I4 & I5 & I6 & I7 & I8 & I9 \\
& D & O & F & F & D & F & O & F & D & F & O & D & F & F & D & F & F & D & O \\
\hline & I & 4 & & & & & & & & & & & & & & & & & \\
& 2 & 5 & 2 & 2 & 7 & 5 & 3 & 7 & 7 & 3 & I & 7 & 3 & I & I & 4 & & & \\
& 3 & 6 & & & & & & & & & & & & & & & & \\
& 5 & I & 5 & 5 & 3 & I & 6 & & & & & & & & & & & & \\
& 7 & 3 & 7 & 7 & 5 & 3 & I & 5 & 5 & I & 6 & & & & & & & & \\
\hline
\end{tabular}

At this stage, one could simply give up hope of finding a satisfactory interpretation of the verso calendar. However, inasmuch as the intention must have been that this calendar should work, it is reasonable to assume that an error has occurred at some point in the sequence. Identifying such an error and correcting it might be regarded as methodologically problematic, but in this case textual support can be invoked. Indeed, near the point where the sequence fails in year I6, we find in the text (verso 11. I3-I4) two scribal errors in succession: the characteristic of small cycle five, year three (i.e. year I4 of the I9-year cycle) is omitted, and the subsequent 
word is jumbled. ${ }^{36}$ This suggests that something has gone wrong at this point in the sequence.

The acronym that is used at the beginning of the passage and again here (on line I4), ח' ח'ש' (DFF), indicates that the characteristic of the third year (year I4) which the scribe has omitted should be 'full'. But I wish to propose that this is an error: the acronym should actually be ' characteristic of year I4 that is missing in the text should therefore be כסדרן, orderly. ${ }^{37}$ It is conceivable, in fact, that the word that the scribe omitted was indeed כסדרן, and that he omitted it precisely because it conflicted with the

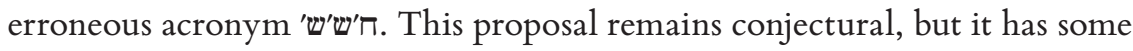
textual basis, and it enables us to determine how the verso calendar might have worked.

TABLE 3 The verso calendar with textual correction

\begin{tabular}{lllllllllllllllllllll}
\hline $\begin{array}{l}\text { Year in } \\
\text { cycle }\end{array}$ & I & 2 & $\mathbf{3}$ & 4 & $\mathbf{5}$ & 6 & 7 & $\mathbf{8}$ & 9 & IO & II & I2 & I3 & I4 & I5 & I6 & I7 & I8 & I9 \\
& D & O & F & F & D & F & O & F & D & F & O & D & F & O & D & F & F & D & O \\
\hline & 2 & 5 & 2 & 2 & 7 & 5 & 3 & 7 & 7 & 3 & I & 7 & 3 & I & 7 & 3 & 3 & I & 4 \\
\hline
\end{tabular}

Note: The textual correction, $\mathrm{O}$ in year $\mathrm{I}_{4}$, is indicated in bold.

As can be seen from TABLE 3, the assumption of 'orderly' for year I4 yields a full sequence of possible New Year days. The only remaining problem, however, is the last New Year in the sequence: it falls on a forbidden day, Wednesday (4). This last day is also problematic for another reason: if the New Year is Wednesday and the I9th year is orderly, the following New Year (in year I of the next cycle) will fall on Tuesday, not on Monday, and the cycle will therefore not be repeated. Both problems, however, can be remedied with one single solution: by bringing forward the New Year of year 19 from Wednesday to Tuesday.

What I am suggesting is not a further textual correction, but a practice that is common in cyclical calendars, and that consists in 'skipping' a day at the end of the cycle, in order to ensure the return to the beginning of the

36. See above, nn. I7-I8.

37. DFD, with the third year (year I4) defective, is not a viable option, because this would cause the New Year in year is to fall on Friday, which is forbidden. 
cycle. In Christian Easter cycles, the practice of shortening the last lunar year or month of the cycle by one day is known under the Latin word saltus, 'jump' or 'skip', and attested already in the fourth century. ${ }^{38}$ In the context of our calendar, a saltus could be achieved by making the I8th year of the cycle, which is defective, a 'hyper-defective' year'; that is, by deducting an additional day from one of its 30-day months (e.g. Shevat) - unthinkable in the later rabbinic calendar, but conceivable perhaps in an earlier period. This would lead to the last New Year occurring on Tuesday, and a return to Monday at the beginning of the next cycle (see T A B L E 4). The verso calendar would be thereby completely reconstructed.

тавце 4 The verso calendar with textual correction and saltus

\begin{tabular}{lllllllllllllllllllll}
\hline $\begin{array}{l}\text { Year in } \\
\text { cycle }\end{array}$ & I & 2 & $\mathbf{3}$ & 4 & $\mathbf{5}$ & 6 & 7 & $\mathbf{8}$ & 9 & IO & II & I2 & I3 & I4 & I5 & I6 & I7 & I8 & I9 \\
& D & O & F & F & D & F & O & F & D & F & O & D & F & O & D & F & F & D & O \\
\hline & 2 & 5 & 2 & 2 & 7 & 5 & 3 & 7 & 7 & 3 & I & 7 & 3 & I & 7 & 3 & 3 & I & $\mathbf{3}$ \\
\hline
\end{tabular}

Note: The saltus, resulting from a hyper-defective year $\mathrm{I} 8$, is indicated in bold.

\section{The calendars of $\mathrm{T}-\mathrm{S} \mathrm{K}$ 2.27: the recto calendar}

The interpretation of the recto calendar is more straightforward and does not require any conjecture. The recto calendar operates very differently, on the basis of a set of fixed rules. Nevertheless, as I shall show, these rules have the virtue of yielding a repetitive cycle too.

The rules of the recto calendar are presented in two versions. In the first version (recto 1l.I-II) the rules are laid out in full. Thus, when the New Year falls on Sunday the year is orderly, in both plain and intercalated years; when it falls on Monday the year is orderly in intercalated years, and full in plain years, and so on. The second version (11. II-I6) presents the same rules in an abbreviated form, by assuming that all years are orderly unless otherwise stated. ${ }^{39}$ In this second version, references to orderly years are therefore

38. Or saltus lunae, 'jump/skip of the moon'. See, for example, B. Blackburn and L. HolfordStrevens, The Oxford Companion to the Year (Oxford: Oxford University Press, 1999), pp. 80I-3.

39. As if to compensate for its brevity - but actually running counter to it - this second version spells out in full the names of the months (Marheshwan and Kislew). Why it does so is unclear. 
omitted (hence the entire omission, for example, of Sunday and Tuesday), and the rules are brought down to the following (TABLE 5): $:^{40}$

TABLE 5 The abbreviated rules of the recto calendar (11. II-I6)

\begin{tabular}{lll}
\hline New Year & Year plain/intercalated & Year characteristic \\
\hline Monday & Plain & Full \\
Thursday & Intercalated & Defective \\
Saturday & Intercalated & Defective \\
Saturday & Plain & Full \\
\hline
\end{tabular}

Note: In all other options the year is orderly.

The rationale of these rules is very simple: they are the necessary outcome of the rule prohibiting New Years on Wednesday and Fridays, and indeed they are designed to prevent the occurrence of any New Year on these forbidden days. The basic rule of the recto calendar is that all years are meant to be orderly; but if this would cause the following New Year to fall on Wednesday or Friday, then the length of the year must be altered: thus if the year is plain, it is made full, and if the year is intercalated, it is made defective. For example, a year beginning on Sunday is always orderly, as the following New Year will be on a Thursday (in a plain year) or Saturday (in an intercalated year), both of which are allowed; whereas if the year begins on Monday, it can be orderly if the year is intercalated (with the next New Year on Sunday), but it cannot be orderly if plain (because then the next New Year will be on Friday); that is why it must be made full. The reason why plain years are made specifically full and intercalated are made specifically defective is presumably to avoid years that are deemed excessively short (defective and plain) or excessively long (full and intercalated). ${ }^{41}$

On the basis of these rules, it is easy to reconstruct a sequence of years, provided the cycle of intercalations is known. It is reasonable to assume that

40. The rules could have been abbreviated further with a statement that Saturday is always followed by Thursday (in the next year, whether this year is plain or intercalated - this need not be specified). However, this would introduce a change of formulation (giving the day of the week of the following New Year, rather than the characteristic of the present year), which one might have good reason to avoid.

4I. This principle is not followed in the verso calendar, where many intercalated years are full and many plain years are defective. 
the I9-year cycle of the verso calendar would have been used here, although any I9-year cycle would probably yield a similar result. The sequence, accordingly, can be laid out as in TA вLE 6, starting arbitrarily on a Sunday; the three cycles in the table follow each other consecutively. Thus, if the first New Year is on Sunday (I) the year will be orderly, and as the year is plain the next New Year will fall on Thursday (5); as this New Year is on Thursday, and the year again is plain, the year will be orderly and the next New Year will fall on Monday (2), and so on.

тавце 6 Sequence of New Years in the recto calendar

\begin{tabular}{llllllllllllllllllll}
\hline & I & $\mathbf{2}$ & $\mathbf{3}$ & 4 & $\mathbf{5}$ & $\mathbf{6}$ & $\mathbf{7}$ & $\mathbf{8}$ & $\mathbf{9}$ & IO & II & I2 & I3 & I4 & I5 & I6 & I7 & I8 & I9 \\
\hline Cycle I & I & 5 & 2 & I & 5 & 3 & 7 & 5 & 3 & 7 & 5 & 3 & 7 & 5 & 3 & 7 & 5 & 2 & 7 \\
Cycle 2 & 5 & 2 & 7 & 5 & 2 & I & 5 & 2 & I & 5 & 2 & I & 5 & 2 & I & 5 & 3 & 7 & 5 \\
Cycle 3 & 3 & 7 & 5 & 3 & 7 & 5 & 2 & 7 & 5 & 2 & 7 & 5 & 2 & 7 & 5 & 2 & I & 5 & 2 \\
\hline
\end{tabular}

As тAвLE 6 shows, at the end of the third consecutive I9-year cycle one returns to the beginning of the first cycle ( 2 in an intercalated year is orderly, hence the next year is I). This means that the calendar constitutes a full, grand cycle of three I9-year periods; like the verso calendar, the recto calendar is cyclical. ${ }^{42}$

It is important to stress, however, that this cycle is not mentioned in our text, either explicitly or implicitly. It may be regarded as the fortuitous result of a set of rules that was not designed for the construction of any cycle, but only for the prevention of the New Year on Wednesday and Friday. It is not impossible, therefore, that the author of our text was himself unaware that these rules yielded a cycle of three i9-year periods.

It should also be noted that if there is no fixed cycle of intercalations, the recto calendar loses its cyclicity and there is no cycle at all. This could have applied, for example, in a period when the I9-year cycle of intercalations was not yet in use. This confirms that the recto calendar is not inherently cyclical; it only produces a cycle when reckoned together with a I9-year intercalation cycle.

42. As the table shows, it is possible to start the $3 \times$ I9-year cycle on Sunday, Tuesday or Thursday. If one starts the first I9-year cycle from a Saturday, by the second year the New Year is on Thursday, and one is brought back to the same cycle as that starting from Sunday. If one starts from a Monday, one runs through a I9-year sequence ending on Monday, whereupon one returns to a cycle starting from Sunday. 


\section{Cyclicity and lunar accuracy}

As mentioned above, both recto and verso calendars have in common that they do not refer to the molad or use it. Whether the New Year corresponds to the day of the molad (lunisolar conjunction, or astronomical new moon), or occurs for instance one or two days later (when the new moon crescent is most likely to become visible), is not specified and, in the context of these calendars, does not actually matter. Provided a starting point (or 'epoch') is set, no matter how exactly, the New Year sequences of the recto or verso calendars can be reckoned without need for any additional information. In this respect, the calendars of T-S K 2.27 function similarly to the Christian Easter calendars, which are based solely on numerical cycles and are not defined by any astronomical criterion such as the molad or lunisolar conjunction.

Nevertheless, it must be assumed that as Jewish calendars, and similarly to the Christian Easter calendars, the calendars of T-S K 2.27 were intended to be lunar; and in this respect an issue must be made of their astronomical accuracy. The recto calendar recurs in a cycle of 57 years $(3 \times 19)$, which in this calendar add up, when counted, to 20,804 days. This number is, necessarily, a multiple of seven, which means that the New Year returns to the same day of the week at the end of 57 years, and the cycle recommences. In astronomical terms, however, this number is grossly inaccurate. In order to keep up with the moon, a I9-year cycle must number on average about 6,939 $2 / 3$ days, hence 57 years must number about 20,819 days. This means that anyone using the recto calendar would find themselves, at the end of the 57-year cycle, as much as Is days behind the moon - at the full moon instead of the new one. It goes without saying that for lunar calendar users a calendar such as this is completely useless.

More precision could have been achieved, for the recto calendar, if the rule had been added that a plain year with the New Year on either Tuesday or Thursday is full (rather than orderly). This modification would violate the calendar's principle that all years are orderly by default, but it would not violate its principle of avoiding years that are excessively short (defective and plain) or excessively long (full and intercalated)..$^{43}$ As тавLE 7 shows,

43. Violating in addition this latter principle, by making some intercalated years full (or some 
adding this rule for Tuesday (' 3 full'), Thursday ('s full'), or both, reduces the calendar to a single, repetitive cycle of 19 years.

TAвLе 7 Recto calendar with modified rules (three options)

\begin{tabular}{lccccccccccccccccccc}
\hline & I & $\mathbf{2}$ & $\mathbf{3}$ & 4 & $\mathbf{5}$ & 6 & $\mathbf{7}$ & $\mathbf{8}$ & $\mathbf{9}$ & IO & II & I2 & I3 & I4 & I5 & I6 & I7 & I8 & I9 \\
\hline 3 full & I & 5 & 2 & I & 5 & 3 & I & 5 & 3 & I & 5 & 3 & I & 5 & 3 & I & 7 & 5 & 2 \\
5 full & 3 & 7 & 5 & 3 & 7 & 5 & 3 & 7 & 5 & 3 & 7 & 5 & 3 & 7 & 5 & 3 & 2 & 7 & 5 \\
Both full & 2 & 7 & 5 & 3 & I & 7 & 5 & 3 & 2 & 7 & 5 & 3 & I & 5 & 3 & I & 7 & 5 & 3 \\
\hline
\end{tabular}

If either Tuesday or Thursday is chosen to be made full in plain years, the outcome is that a I9-year cycle amounts to 6,937 days, a multiple of seven, hence a repetitive cycle. However, this cycle still falls short of an accurate

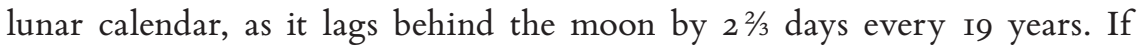
both Tuesday and Thursday are made full in plain years, the I9-year cycle amounts to 6,944 days, again a multiple of seven and a repetitive cycle; but it is then $4^{1 / 3}$ days in excess of the moon. These options are marginally more accurate than the recto calendar of T-S K 2.27, and have the advantage of constituting a shorter cycle of just 19 years; but in practical terms they are just as unusable.

The fact that the recto calendar does not seek to alter its rules, as for example in TAвLE 7, so as to obtain a more simple cycle of 19 years, demonstrates further that its purpose is not to generate a cycle: as argued above, all that matters to the recto calendar is to provide a set of rules for the prevention of the New Year on Wednesday and Friday. But, even so, the rules on their own, regardless of any cycle, are themselves inherently inaccurate: for there are not enough full years, within this set of rules, for the calendar to keep up even approximately with the moon. A lunar calendar that is astronomically accurate needs to have more full years than orderly and defective ones, because the average length of a lunar month exceeds $29^{1 / 2}$ days. The error of the recto calendar is partly the result of a misguided principle that all months should be orderly by default, and that intercalated years can never be full.

The verso calendar, in contrast, is much more versatile in its use of full years, many of which apply to intercalated years. But this does not prevent

plain and intercalated years full, in various combinations), generally yields very similar results: single 19-year cycles with the same margins of inaccuracy. 
this calendar, which is primarily a fixed cycle, from being just as inaccurate as the recto. The cycle of the verso calendar, as I have reconstructed it, amounts to 6,937 days, which means that it falls behind the moon by $2^{2 / 3}$ days every I9 years. This discrepancy is inevitable for any 19 -year cycle that returns to the same day of the week, and whose total number of days is therefore a multiple of seven. An accurately lunar 19-year cycle must count on average about $6,939^{2 / 3}$ days, which does not approach any multiple of seven; it is not reducible, therefore, to a number of full weeks.

All fixed calendars, and especially short-span cyclical calendars, must compromise to a certain extent with astronomical accuracy. The calendars of T-S K 2.27, however, are a particularly bad case. They contrast in this respect with Christian Easter cycles, which, as I have suggested above, the calendars of T-S K 2.27 may have attempted to imitate, but which achieved a much greater degree of astronomical accuracy. This is because Easter cycles are constructed with the Julian calendar as reference point, in such a way that after 19 years the lunar dates of Easter recur on the same dates in the Julian calendar. The correspondence of I9 Julian years with a whole number of lunar months ( 235 in total) is sufficiently close to preserve the lunar, astronomical accuracy of Easter cycles, at least over a few centuries. ${ }^{44}$ The calendar cycles of T-S K 2.27, however, do not use the Julian calendar (rabbinic sources never use it); instead, their only reference point is the seven-day week. This inevitably leads to astronomical inaccuracy, because there is no correspondence between the week and the number of days in the I9-year cycle.

Consequently, the cyclical calendars of T-S K 2.27 are bound to fail as lunar calendars. This leads to the conclusion that these calendars were theoretical and could never have been usefully applied in practice.

\section{T-S K 2.27 and the origins of the fixed rabbinic calendar}

The remarkable, 'primitive' calendar text of T-S K 2.27 enables us to fill gaps in our knowledge of the history and origins of the fixed rabbinic calendar. It provides, indeed, a missing link between the calendar principles and rules

44. In fact, I9 Julian years exceed 235 lunar months by about I.45 hours, which accumulate to nearly one day in three centuries. This discrepancy, which led to a slow drift of the Easter calendar from the moon, was noticed in the early Middle Ages and led, eventually, to the reform of the calendar by Pope Gregory in I582; see C.P.E. Nothaft, Dating the Passion: The Life of Jesus and the Emergence of Scientific Chronology (200-1600) (Leiden: Brill, 20II). 
attested in Talmudic literature, and the fixed calendar that emerged in the ninth century and that is known today as the standard Jewish calendar.

The rules of the recto calendar, which are designed to prevent the occurrence of the New Year on Wednesday and on Friday (but not on Sunday), are congruent with the passage in the Palestinian Talmud, $y$ Megillah I:2, 7ob, which only prohibits the New Year on these two days. It is thus conceivable that the recto calendar was already formulated in the Talmudic period, although the prohibition of only Wednesday and Friday is still attested in seventh-century sources (see above, near note 28 ), so the recto calendar could also date from this later period.

As we have seen, the rules of the recto calendar are astronomically inadequate and lead to a significant discrepancy from the moon. However, when the recto calendar was originally formulated, it may have been intended only to simplify the calendar calculation, without necessarily predetermining it or constraining it. If its rules were just used as guidelines and not strictly adhered to, the discrepancy from the moon could have been corrected from time to time on an ad hoc basis. This would have been all the more plausible in a period when no fixed cycle of intercalations had yet been introduced (as I shall argue elsewhere, the I9-year cycle is likely to have been introduced not much before the eighth century, when it is first attested in rabbinic sources). But once a fixed cycle of intercalations was introduced, and the calendar as a whole became increasingly fixed, the rules of the recto calendar would have become unworkable and of little practical use. At that point, perhaps at some time in the eighth century, the recto calendar would have been abandoned as obsolete.

The adoption of a fixed I9-year cycle of intercalations, perhaps in the eighth century, may be regarded as a part of a more general attempt to standardize and fix the Jewish calendar. The verso calendar, which I would date to the eighth century, exemplifies such an attempt. It also suggests the influence, in this context, of the Christian Easter calendars (whose history went back to the third-fourth centuries). ${ }^{45}$ The verso calendar, indeed, shares several features of the Easter cycles: a fixed cycle of I9 years which determines

45. On the origins and history of Christian Easter cycles, see for example A.A. Mosshammer, The Easter Computus and the Origins of the Christian Era (Oxford: Oxford University Press, 2008); S. Stern, Calendars in Antiquity. Empires, States, and Societies (Oxford: Oxford University Press, 20I2), pp. 326-30, 388-4II. The verso calendar is clearly much later than the first Easter cycles, and belongs to a period when Easter cycles had been long established in Christianity. 
both intercalated years and New Year dates; a simple reckoning based entirely on whole days (as opposed to the complex, highly fractional calculation of the molad, which is absent here); and, according to my reconstruction, the use of saltus (omission of one day) at the end of the cycle. The verso calendar was thus arguably based on a Christian model. Whether the motivation was to imitate the Christians, or to outdo them, or simply to create a reliable and accurate fixed calendar, is a matter of speculation. But, unlike the Easter calendars, the verso calendar was fundamentally inaccurate and could never have been used in practice, even in the period of just one cycle (at the end of one cycle, indeed, the discrepancy with the moon would have accumulated to over two days). This calendar was therefore inherently short-lived, and if it were ever used it must have soon been abandoned.

In contrast to the Easter cycles, which tracked the moon relatively accurately by being anchored in the Julian calendar, the rabbinic verso calendar only had the seven-day week as reference point, which was bound to lead to significant discrepancies from the moon. The realization that the Christian model could not be adapted for Jewish purposes - as evident from the failure of the verso calendar - is what might have led to the search for an alternative model. The main issue that had arisen, astronomical accuracy, could only be resolved - in the absence of a reference point like the Julian calendar - in a scientific manner, and this had to involve the precise calculation of the astronomical new moon. This is what may have led to the innovative idea of using astronomical data, the molad calculation, in the rabbinic calendar. Thus, the primitive rabbinic calendars of T-S K 2.27 not only shed light on the earlier stages of the fixation of the rabbinic calendar, but also explain perhaps why interest in the molad calculation developed in the eighth century, and why the molad was eventually adopted, in the early ninth century, as the foundation of the rabbinic calendar in its final form. ${ }^{46}$

46. On the history of the molad calculation, see above near n. 30 . 


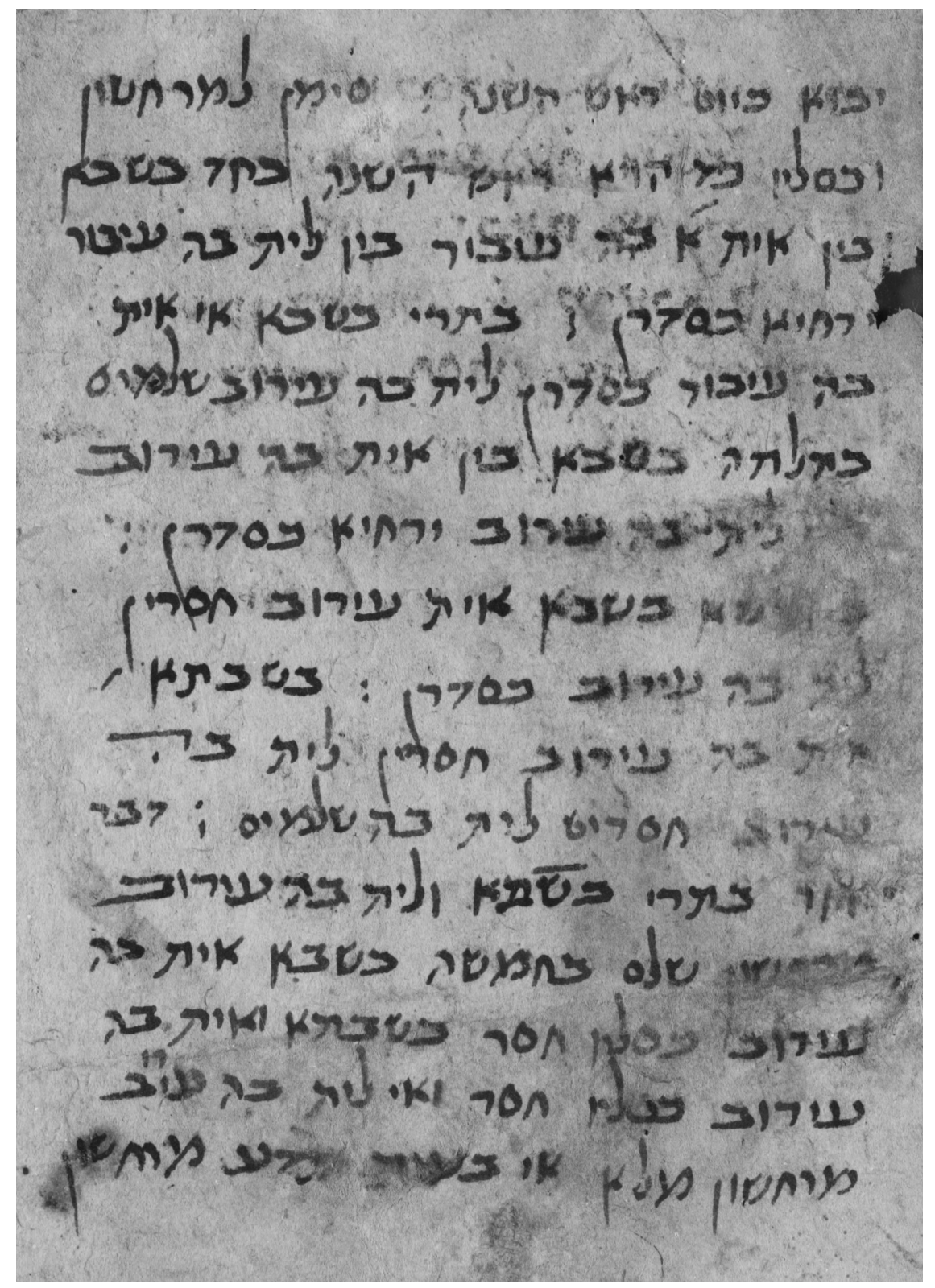

FIG. I T-S K 2.27 recto left, with permission of the Syndics of the Cambridge University Library. 


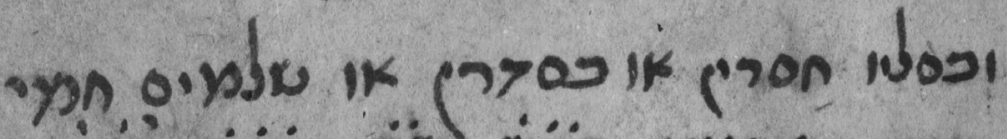

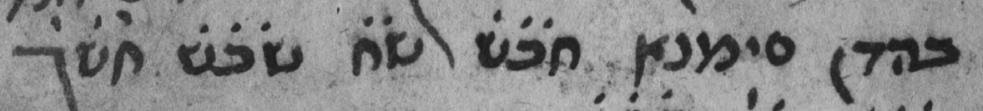
Lut ialins puse jice in vin

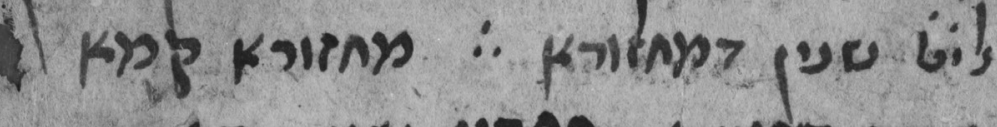

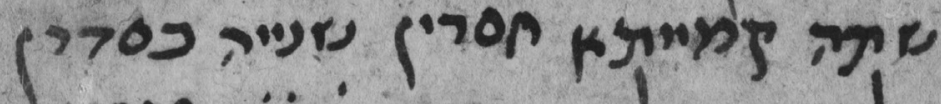

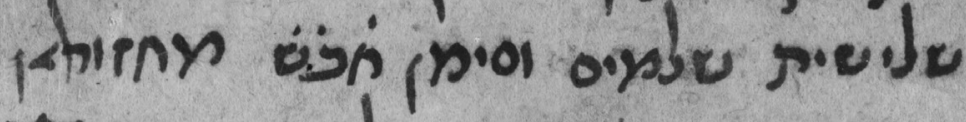

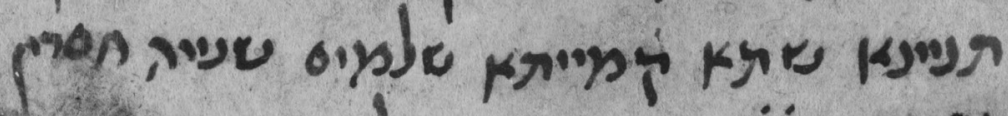

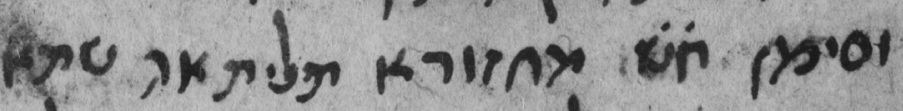
j.vibe pos ine ande firmpts

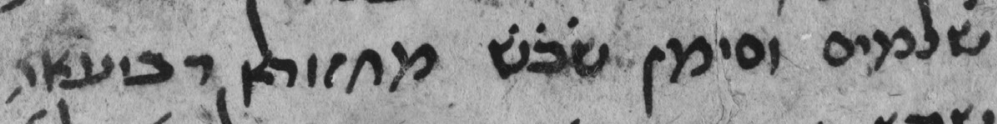

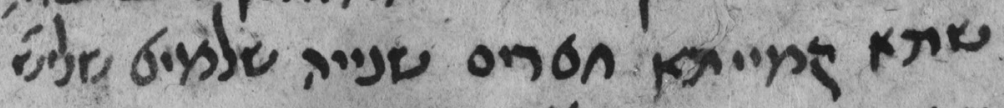

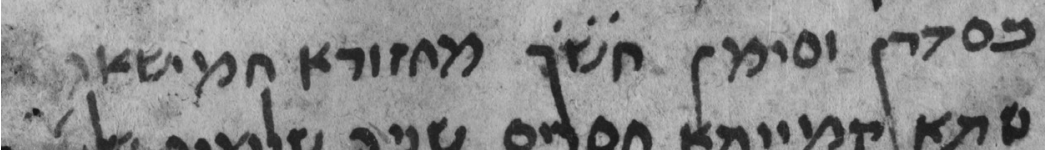
- Yla anybrs seve onon privesp kro

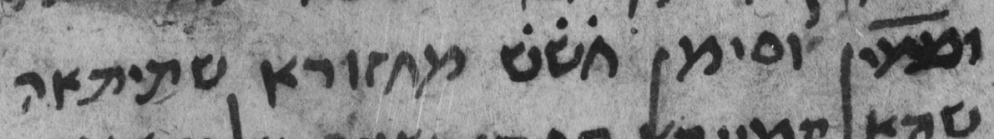

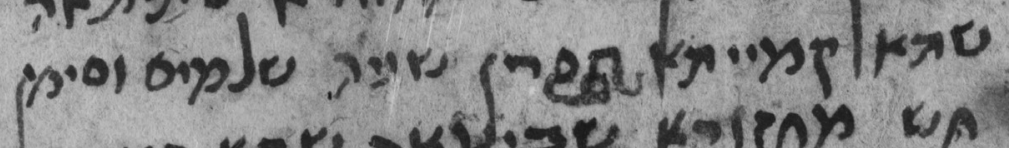

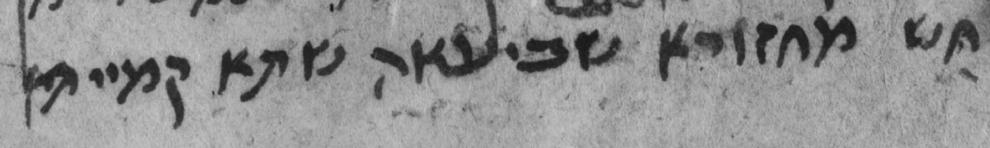

$T-S, K 2,27$

FIG. 2 T-S K 2.27 verso right, with permission of the Syndics of the Cambridge University Library. 